thenceforth overseas students should pay arbitrarily defined "economic fees", and with the later and equally arbitrary decision that direct support for the universities must be reduced by 8.5 per cent, it is natural that the universities should assume that the minister's intentions towards the University Grants Committee are malevolent.

Some consideration should therefore be given to the more or less moderate tone of the bulk of the Joseph letter, which among other things repeats the promise that direct support for the universities will level out when the academic year 1983-84 is over (at least if inflation does not run away again), pats the grants committee on the back for its selective distribution of reduced funds among British universities, applauds the more recent decision to allocate extra funds to biotechnology (see Nature 20 May, p.173) and sympathizes with the general concern that, as things are, the recruitment of "young able people" into the university system is virtually impossible. The letter even acknowledges that the grants committee has acted sensibly in revising some of the targets for student numbers at particular universities in the light of some special pleading, even though these decisions will marginally shade the government's insistence that student numbers should be fixed from on high. How, it may be asked, can such a reasonable minister have malign intentions towards the independence of the system?

On the evidence of the minister's letter, part of the trouble is simply that the British government remains in a muddle about higher education. Student numbers are a good illustration. The most illiberal feature of the present university contraction is that each British university has been given a ceiling for the number of students from the United Kingdom and European Community countries it can have on its books in 1983-84. The result, since most numbers are reductions, is that much educational plant will be less than fully used and that universities will not be able to work their way out of financial trouble by doing their jobs more efficiently. (The threat that if they take in more than their allotted quota of students they will be penalized financially has not been withdrawn even though the grants committee did not repeat it in the letters sent to individual universities in May.) Yet this offensive system, and the uncertainties that go with it, arises simply from the government's fear that if the universities exceed their quotas, the cost will be increased of maintenance awards to students, paid by local authorities but then laid off on the central government. Is it really beyond the wit of a government anxious to play a more active part in the planning of higher education to devise some different system of subsidizing students, one that would combine the legitimate objective of controlling the total cost with flexibility on numbers?

The Joseph letter is also muddled about the relationship between the universities and the higher education institutions formally supported (but with funds from the central government) by local authorities, chiefly the polytechnics. The coexistence of these two kinds of institutions in what is called the "binary system" is strictly a political matter, for the polytechnics were established (in the 1960s) because of the then government's conviction that there was a need for a more down to earth system of higher education than the universities chose to provide. The experiment has been only a patchy success but, to its credit, the present government has been trying since before Sir Keith Joseph's time at the Department of Education and Science to wrest full control of the polytechnics away from the local authorities. Indeed, there is now a National Advisory Body for the polytechnics in England, and there may soon be one for those in Wales. The Joseph letter now asks that the grants committee and its counterpart committee for the polytechnics should consult with each other and that, as well as working out schemes for collaboration between individual universities and polytechnics, they should also help to define the relationship between the two sectors of higher education. The objective is sensible and should have been sought a long time ago. But the issue, eminently political as it is, must in the long run be settled by the government,

What the Joseph letter says about the support of university research is more alarming. The letter applauds the grants com- mittee's intention to play its part in the dual support system, welcomes the Merrison report on the subject and goes on to approve of the principle that there should be "selectivity of funding" not merely by the research councils that provide project grants for university research but also by the grants committee, which is responsible for supporting a "basic level of research activity'. What, suspicious minds will ask, is the minister approving? A decision, not yet taken, that in future there will be two kinds of universities - those equipped for research and those which are not? The Merrison committee rightly argued that British universities are less deliberate than they should be in using the grants committee's general subvention for research, and acknowledged that even if the job were done intelligently, some university departments would be able to mount research programmes only in collaboration with others. But the Merrison committee also rejected the principle of a close correlation between research support provided by the grants committee and the research councils, for that would only undermine the dual support system as a whole.

The fear that the Department of Education and Science does not properly understand the system of higher education in whose management it now seeks a more decisive role is the worry underlying the declaration that in future ministers must take more responsibility for it. Higher education may be too important to be left to academics, but the British government hardly seems their natural successor. By all accounts, the present intention is merely that Sir Keith Joseph should from time to time give the grants committee general guidance about its sense of where priorities lie. The difficulty is that the government's sense of priorities is unlikely to make academic sense. The present concern is somehow to shape higher education so as to contribute to national prosperity, a question with which university systems elsewhere than in Britain have wrestled for decades, but without much success. The danger is that from frustration, ministers will slip into the habit of making their priorities particular, issuing edicts such as "Let there be more engineers!", "Let there be more computer engineers!" or even "Let there be more computer engineers training on British equipment!" Sir Keith Joseph himself may be aware of the dangers. But once the precedent of intervention has been established, his successors will be provided with countless opportunities for foolish interference.

\section{Pity the luckless British}

\section{Great wars are said to bring out the best in people. Small wars appear to reveal the worst.}

Who would have predicted that a mere month after a famous victory in the Falklands, the British government would be deeply embarrassed by a concatenation of domestic blunders - the false assumption that it would be able to comply with its bargain with its opponents when it won consent to send an amphibious force to the South Atlantic by mounting a Parliamentary enquiry on its own terms of reference? the discovery that an intruder could climb into Buckingham Palace and sit on the Queen's bed for ten minutes before being apprehended? and the growing likelihood that there has been another monumental breach of national security at one of the most technically advanced intelligence centres in the world? The British legend, especially common since the. Second World War, is that the British are good at fighting (and even winning) wars but less endowed with flair in times of peace. The truth is different, as the events of the past few months have shown all too clearly. Most probably, the Parliamentary enquiry will show that the Falklands war was unnecessary, if not the consequence of a poor appraisal of intelligence then of indolence. Much the same is likely to be the case of the other conspicuous failures of public administration, in the past few weeks. But who, or what, is to blame? The simple answer is the Civil Service, and its perennial pride in its technical innocence. The charge that this is so has been made repeatedly, and most governments have agreed that it is correct. When will one of them do something? 